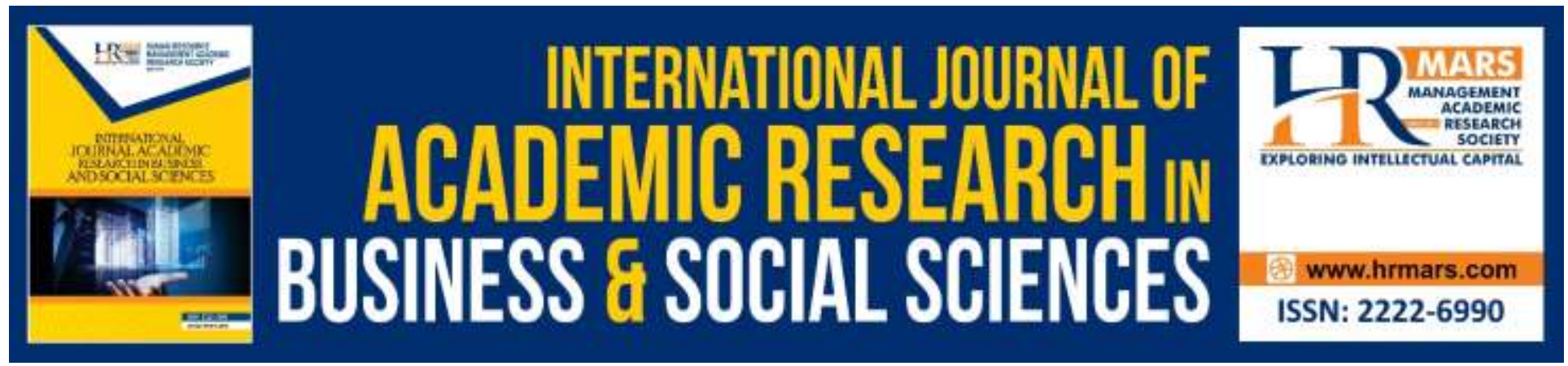

\title{
Dignified Human Corpse in Disaster: A Need of New Treaty
}

\author{
Loh Ing Hoe, Roslan Umar, Mohd Khairul Amri Kamarudin, Chong Ju Lian
}

To Link this Article: http://dx.doi.org/10.6007/IJARBSS/v8-i5/4141

DOI:10.6007/IJARBSS/v8-i5/4141

Received: 20 August 2017, Revised: 15 Sep 2017, Accepted: 13 April 2018

Published Online: 29 May 2018

In-Text Citation: (Hoe, Umar, Kamarudin, \& Lian, 2018)

To Cite this Article: Hoe, L. I., Umar, R., Kamarudin, M. K. A., \& Lian, C. J. (2018). Dignified Human Corpse in Disaster: A Need of New Treaty. International Journal of Academic Research in Business and Social Sciences, 8(5), 537-547.

\section{Copyright: (c) 2018 The Author(s)}

Published by Human Resource Management Academic Research Society (www.hrmars.com)

This article is published under the Creative Commons Attribution (CC BY 4.0) license. Anyone may reproduce, distribute, translate and create derivative works of this article (for both commercial and non-commercial purposes), subject to full attribution to the original publication and authors. The full terms of this license may be seen at: http://creativecommons.org/licences/by/4.0/legalcode

Vol. 8, No. 5, May 2018, Pg. 537 - 547

http://hrmars.com/index.php/pages/detail/IJARBSS

JOURNAL HOMEPAGE

Full Terms \& Conditions of access and use can be found at http://hrmars.com/index.php/pages/detail/publication-ethics 


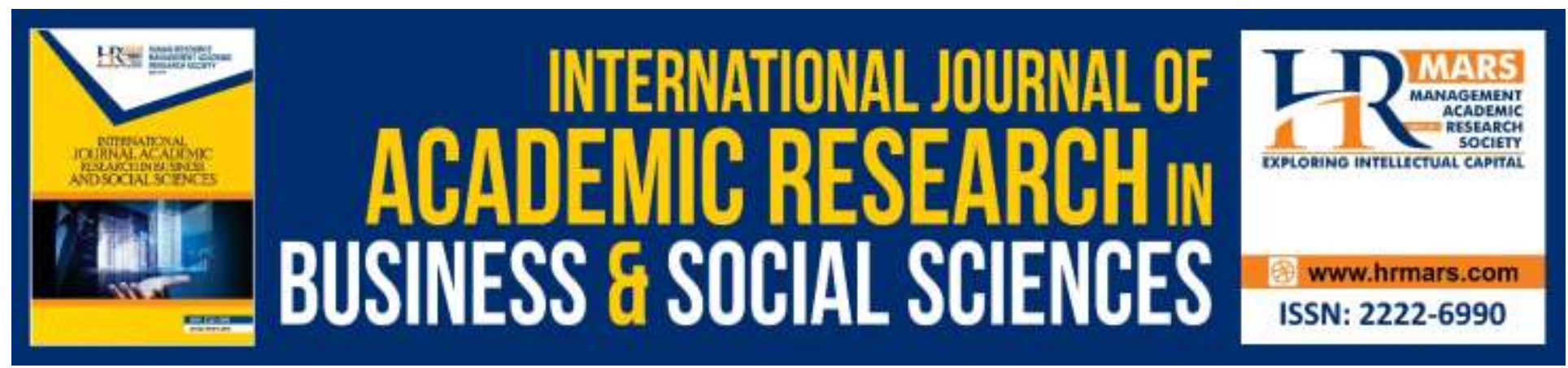

\title{
Dignified Human Corpse in Disaster: A Need of New Treaty
}

\author{
'Loh Ing Hoe, ${ }^{2}$ Roslan Umar, ${ }^{2}$ Mohd Khairul Amri Kamarudin, \\ ${ }^{3}$ Chong Ju Lian
}

${ }^{1}$ Faculty of Business, Curtin University Malaysia, CDT 250, 98009 Miri Sarawak, Malaysia.

${ }^{2}$ East Coast Environmental Institute (ESERI), Universiti Sultan Zainal Abidin Kampus Gong Badak, 21300 Terengganu, Malaysia, ${ }^{3}$ Biodiversity Program, School of Marine and Environmental

Sciences, Universiti Malaysia Terengganu, 21030 Kuala Terengganu, Terengganu.

Email: ing.hoe.loh@curtin.edu.my,roslan@unisza.edu.my,mkhairulamri@unisza.edu.my

julian@umt.edu.my

\begin{abstract}
Humans are the greatest creatures in the world. Our intelligence defined our dignity as human beings and our dignity should be respected. Therefore, human rights are the basic rule of human existence. However, human rights are seldom applied to human corpse. Most countries do not have specific legislation related to the management of human corpse after disaster and additionally, international law also failed to propose a treaty specifically dealing with the management of human corpse after disaster. Therefore, this paper attempts to analyse the related treaties, customary international humanitarian law and soft law pertaining to the management of human corpse. Qualitative methodology with analytical, historical and comparative approaches was used in this study. Results indicate that there is no existing specific treaty that governs the management of human corpse after disaster.
\end{abstract}

Keywords: Human, Corpse, Disaster, International Law, Human Rights.

\section{Introduction}

International law plays an important role in creating new practices and replacing certain existing practices. Article 38(1) of Statute of the International Court of Justice lists down the sources of international law which includes treaty, custom, general principle of law, judicial decision and teachings of the most highly qualified publicists. Although there are existing treaties and customary international humanitarian law related to management of human corpse in war, none of these laws deal directly with management of human corpse in the event of disaster. As a soft law in nature, the Management of Dead Bodies in Disaster Situations, Disaster Manuals and Guidelines Series, No.5, Management of Dead Bodies After Disaster: A Field Manual for First Responders, and Disaster Victim Identification Guide is the main guideline in the management of 
human corpse after disaster. However, soft law plays a persuasive role rather than a binding role. Therefore, its effectiveness in managing human corpse after disaster is still questionable as failure to follow those guidelines will not impose any responsibility to any State. Without binding treaty governing the disaster management of human corpse, it will be hard if not impossible to propose any municipal law related to disaster management of human corpse within the internal affairs of a country.

\section{Definition}

\section{Human Dignity}

The English expression 'human dignity' consists of the predicate 'human' and the noun 'dignity'. The adjective qualifies the noun, thus determining the kind of dignity in question as of the human kind. The adjective has a similar function in the expression 'human being', as it qualifies the noun 'being', to determine the kind of being in question as a being of the human species. 'Human' is etymologically related to the Latin for earth, humus, so that 'human' means what is 'earthly' (as an adjective), or an 'earthling' (as a substantive) (Lebech, 2004). Dignified is an adjective for dignity. Dignity comes from the Latin noun decus, meaning ornament, distinction, honour, glory. Decet is the verbal form (which is impersonal), and means to seem or to show. Dignity means, generally speaking, the standing of one entitled to respect, i.e. his or her status, and it refers to that which in a being (in particular a personal being) induces or ought to induce such respect: its excellence or incomparability of value (Lebech, 2004). When 'human' and 'dignity' are used in conjunction they form the expression 'human dignity', which means the status of human beings entitling them to respect, a status which is first and to be taken for granted. It refers to their highest value, or to the fact that they are a presupposition for value, as they are those to whom value makes sense.

According to Pinker (2008), dignity is a phenomenon of human perception, certain features in another human being which trigger ascriptions of worth. These features include signs of composure, cleanliness, maturity, attractiveness, and control of the body. The perception of dignity in turn elicits a response in the perceiver. Just as the smell of baking bread triggers a desire to eat it, and the sight of a baby's face triggers a desire to protect it, the appearance of dignity triggers a desire to esteem and respect the dignified persons. Pinker (2008) juxtaposed this psychological notion of dignity with the distinctly moral ideal of respect for persons.

\section{Corpse}

According to Duhaime's Law Dictionary, corpse means a dead human body. A corpse is usually described as a human corpse, to distinguish it from animals, and includes any portion of a human corpse. The human remains means the body of a deceased person, in whole or in parts, regardless of its stage of decomposition (Duhaime, 1999). Meanwhile, Oxford Dictionary defines corpse as a dead body, especially of a human being rather than an animal (Law \& Martin, 2013).

\section{Disaster}

In 1992 the United Nations recognized that for an event to be classified as a disaster it must overwhelm the response capability of a community. An international disaster is defined as a serious disruption of the functioning of society, causing widespread human, material, or environmental losses which exceed the ability of the affected society to cope using only its own 
resources (Jha, 2010). Disasters more accurately represent collective stress situations occurring at a community level as a result of major unwanted consequences (Hutton, 2001). Accoring to Gist and Lubin, a disaster is defined by its relationship to community - a cataclysm qualifies as a disaster only to the extent that it overwhelms the capacity of a community to contain and control its consequences (Hutton, 2001). Kume (2006) was in the opinion that regardless the terminology used and the types of event either natural or human, generally there is consensus that a disaster is an event that involves the destruction of property, injury, and/or loss of life; has an identifiable beginning and end; adversely affects a relatively large group of people; is 'public' and shared by members of more than one family; is out of the realm of ordinary experience; and psychologically, is traumatic enough to induce distress in almost anyone.

\section{Problem Statement}

The lack of international treaty governing the management of human corpses after disaster has caused the human corpse been treated disrespectfully. Cremation and mass burial of human corpse are some of the practices which is against the dignity of human right. One should be treated with dignity even though they are no longer alive. Therefore, there is a need of a new treaty to uphold the dignity of human corpse after disaster.

\section{Research Objective}

The research objective was to identify existing international law related to management of human corpse after disaster.

\section{Research Motivation}

This study assists in recommending a new international treaty specifically dealing with management of human corpse after disaster.

\section{Literature Review}

According to Tidball-Binz (2007), proper management of dead body is a core component of disaster response, together with the rescue and care of survivors and the provision of essential services. The proper management of the dead from catastrophes is an essential component of humanitarian response, together with the rescue and care of survivors and the provision and rehabilitation of essential services. Obonyo (2015) pointed out the problem of lack of integrated and coordinated approach that relies on ad hoc measures to handle unexpected disasters.

The International Committee of the Red Cross is firmly advises against mass burials following disasters, as does the World Health Organization, reporting that the act can cause more harm than good. Rushing to bury the dead makes it harder for survivors and relatives of the deceased to deal with their personal tragedies. Without identification of the body, or knowledge of where it might have been buried, family members will not get closure. Nor can they perform the necessary funeral rites according to their religious or cultural beliefs (Amber, 2013).

Harvey et al. (2002) in their book namely Emergency Sanitation, Assessment and Programmed Design have expressed that the cultural requirements and the needs of the families of the deceased should be given priority over public concerns. The process of mourning and burial or cremation will be highly significant and emotional to the family and friends of the deceased. By showing respect to the human corpse, it will help to ease the pain of family members. 
International law has played a very crucial role in providing guidelines for management of human corpse after disaster. However, there is no treaty that directly deals with management of human corpse after disaster. Most of the existing laws are soft law in nature. According to Lang (1999), hard law represents law in its traditional meaning; it is compulsory ("shall"); it reflects a real obligation that must be fulfilled; if it is violated the perpetrator incurs international responsibility, which implies compensation for any loss or repair of any damage caused by the perpetrator's behaviors. Soft law on the other hand, is a relatively new notion; it is of a recommendatory nature ("should"). If it is violated, it entails criticism and the qualification as an unfriendly act. But even these relatively weak consequences of misbehavior can be damaging for the perpetrator; his/her reputation are at stake, which again has a certain impact on the educated and elicit public opinion in our open societies.

According to Anthonio D'Amato, customary international law is binding on all States but its content is less clear as it is not written down as such. Customary international law is created by widespread, representative and uniform practice among States. Its rules, as a result, can only be determined on the basis of extensive research into that practice (D'Amato, 1987).

Therefore, the relevant treaties, international customary humanitarian law and soft law governing the management of human corpse have been identified in this study in order to propose a specific treaty relating to disaster management of human corpse.

\section{Methodology}

Qualitative methodology comprising of analytical, historical and comparative approaches was utilised in this study.

\section{Results and Discussion}

International Law Governing Management of Human Corpse: Treaty, Customary International Law and Soft Law

Source of International law means those origins from where international law attains its authority and coercive agency. The sources of international law are enumerated in Article 38 of the Statute of the International Court of Justice with the four sources listed by Article 38 being: (a) international conventions or treaties establishing rules expressly recognized by the contesting states; (b) customary international law, as evidence of a general practice accepted as law; (c) the general principles of law recognized by civilized nations; and (d) judicial decisions and the teachings of the most highly qualified publicists of the various nations, as subsidiary means for the determination of rules of law. There are some quasi sources of international law that have been suggested, however, none of them can stand in their own right as a new source of international law without relying on the established formal sources. One of the quasi sources of international law which is relevant to the disaster management of human corpse is soft law (Rahman \& Amin, 2014).

\section{Treaty: Geneva Convention and other Protocols}

International humanitarian law, also known as the law of war, or the law of armed conflict, is a set of rules which seeks, during armed conflict, to protect persons who are not or are no longer participating in the hostilities, and to limit methods of warfare. Within this framework, international humanitarian law addresses the handling of corpses including the search, 
identification, and final disposal of human remains resulting from armed conflict. The principles address is the handling of dead bodies in accordance with international humanitarian law includes Convention (I) for the Amelioration of the Condition of the Wounded and Sick in Armed Forces in the Field (Convention I), Convention (II) for the Amelioration of the Condition of Wounded, Sick and Shipwrecked Members of Armed Forces at sea (Convention II), Convention (III) relative to the Treatment of Prisoner of War (Convention III), Convention (IV) relative to the Protection of Civilian Persons in Time of War (Convention IV), Protocol (I) Additional to the Geneva Convention and relating to the Protection of Victims of International Armed Conflicts (Protocol I), and Protocol (II) Additional to the Geneva Conventions and relating to the Protection of Victims of Non-International Armed Conflicts (Protocol II).

According to Article 15 of Convention I, Article 18 of Convention II and Article 8 of Protocol II, all the parties in an armed conflict should, without delay, take all possible measures to seek and collect the dead, without distinction, and to treat them with respect and dignity, avoiding plunder and the dispossession of the same. Additionally, Article 20 of Convention II and Article 120 of Convention IV state that all the parties in an armed conflict should take measures to identify the dead before burying them or burning them. Parties to the conflicts shall ensure that burial or cremation of the dead, carried out individually as far as circumstances permit, is preceded by a careful examination, if possible by a medical examination, of the bodies, with a view to confirming death, establishing identity and enabling a report to be made.

Article 17 of Convention I, Article 120 of Convention III, Article 130 of Convention IV and Article 34 of Protocol I emphasized that bodies shall not be cremated except for imperative reasons of hygiene or for motives based on the religion of the deceased. In case of cremation, the circumstances and reasons for cremation shall be stated in detail in the death certificate or on the authenticated list of the dead. In an armed conflict it is necessary to bury or to burn honorably the dead and to respect their graves. People whose fatal remains cannot be delivered to their family members in an armed conflict will be buried individually and all the graves will be marked. Only exceptionally will collective graves be utilized. Under Article 16 of Convention I, Article 19 of Convention II and Article I of Protocol I, all the parties in an armed conflict have to do everything possible to provide information on the identity, the location, and the cause of the death of the deceased to the responsible authorities or to their relatives.

The standards mentioned above should be respected by the signatory states of the Conventions of Geneva and its Additional Protocols, are probably the oldest provisions regarding the management of human remains although they apply to international and domestic armed conflict situations and not specifically to natural disaster. However, these conventions and protocols listed down very valuable principles because they expressly recognize the importance of prioritizing identification of the dead as a fundamental right.

\section{Customary International Humanitarian Law}

Customary international law, like international treaty law, is recognized as a primary source of public international law. While international treaties are written agreements by which States establish certain rules, customary international law consists of unwritten rules which derive from "general practice accepted as law". Therefore, for a rule of international custom to be established, two elements are required namely: "an objective one, the repeated behaviour of States and a subjective one, the belief that such behaviour depends on a legal obligation (opinio 
juris sive necessitatis)". The objective element is also often referred to as State practice while the subjective element as opinio juris (Wikipedia, 2017). There are three reasons why customary international humanitarian law is extremely important. Firstly, while the Geneva Conventions enjoy universal adherence today, this is not yet the case for other major treaties, including the Additional Protocols. These treaties apply only between or within States that have ratified them. Rules of customary international humanitarian law on the other hand, which is sometimes referred to as "general" international law, bind all States and, where relevant, all parties to the conflict, without the need for formal adherence. Second, customary international law can help in the interpretation of treaty law. It is a well-established principle that a treaty must be interpreted in good faith and with due regard for all relevant rules of international law. With this in mind, one better understands the mandate assigned to the International Committee of the Red Cross (ICRC) by the 26th International Conference of the Red Cross and Red Crescent (Geneva, 1995), when the organization was asked to: prepare, with the assistance of experts in international humanitarian law representing various geographical regions and different legal systems, and in consultation with experts from governments and international organisations, a report on customary rules of international humanitarian law applicable in international and noninternational armed conflicts, and to circulate the report to States and competent international bodies. (Henckaerts \& Doswald-Beck, 2009)

Article 112 of Customary International Humanitarian Law urged each party to the conflict to take all possible measures to search for and collect the dead. This includes permitting the search for and collection of the dead by humanitarian organizations. The obligation to take all possible measures to prevent the dead from being despoiled or the prohibition of the despoliation of the dead is set under Article 113. In addition, Article 114 states the obligation of parties to facilitate the return of the remains of the dead to their families upon their request. As such, this obligation is in keeping with the requirement of respect for family life (Rule, 105).

Article 115 emphasizes that the dead must be buried, if possible, according to the rites of the religion to which they belonged and that they may only be cremated under exceptional circumstances, due to imperative reasons of hygiene, on account of the religion of the deceased or in accordance with the expressed wish of the deceased. Burial should be in individual graves and collective graves may only be used when circumstances do not permit the use of individual graves. Finally, Article 116 required each party to record all available information for identification purposes prior to disposal and to mark the location of the graves.

Soft law: Management of Dead Bodies in Disaster Situations, Disaster Manuals and Guidelines Series, No.5, Management of Dead Bodies After Disaster: A Field Manual for First Responders, and Disaster Victim Identification Guide

Chapter 2 Guidelines Series states that once the survey work is complete and the human remains are removed, they should be gathered at a holding area close to the disaster site where they will be examined or transferred to the site where final examination and disposition will take place. The human remains should be well packed in the bags with corresponding identification, transported in trucks or vans (preferably closed vehicles).

Under Chapter 4 of the First Responders, bodies should be placed in body bags. If these are unavailable, plastic sheets, shrouds, bed sheets, or other locally available material should be utilised. Body parts should be treated as individual bodies and recovery teams should not attempt 
to match the body parts at the disaster scene. Body recovery teams work most effectively in two groups: one to take bodies to a nearby collection point and a second to take them to identification or storage areas. Noting the place and date where the body was found assists identification. Personal belongings, jewelry, and documents should not be separated from the corresponding remain during recovery, but only during the identification phase. Stretchers, body bags, and flatbed trucks or tractor-trailers can be used to transport bodies. Chapter 6 of Disaster Victim Identification Guide states that a body transport team must be assigned responsibility for the movement of bodies from and to the morgue station with bodies or body parts should be transported in vehicles or on gurneys or tables. Chapter 12 notes that every body or body part is assigned a number with each individual number only assigned once. In addition, the numbers will be written on a waterproof label or tag which is attached to the body using cable straps.

Chapter 2 of the Guidelines Series suggests that dead bodies should be well packed and refrigerated, if possible. The recommended temperature for preservation is $4^{\circ} \mathrm{C}$. However, freezing the bodies will make immediate tasks such as detailed description for identification purposes more difficult. Freezing will also interfere with autopsy. Chapter 5 of First Responders has more detailed guidelines in terms of storage of dead bodies. Regardless of storage option, each body or body part should be kept in a body bag or wrapped in a sheet before storage. In addition, waterproof labels such as paper in sealed plastic with a unique identification number should be assigned. Refrigeration of bodies is recommended between $2^{\circ} \mathrm{C}$ and $4{ }^{\circ} \mathrm{C}$ while refrigerated transport containers used by commercial shipping companies can be used to store up to 50 bodies. Dry ice [carbon dioxide $\left(\mathrm{CO}^{2}\right)$ frozen at $-78.5^{\circ} \mathrm{C}$ ] may be suitable for short-term storage. However, dry ice should not be placed on top of the bodies, even when wrapped, because it damages the body. A low wall of dry ice (i.e., $0.5 \mathrm{~m}$ high) should be built around groups of about 20 bodies and a cover of a plastic sheet, tarpaulin, or tent used. About $10 \mathrm{~kg}$ of dry ice per body, per day is needed, depending on outside temperature. Dry ice must be handled carefully as it causes "cold burns" if touched without proper gloves. The use of ice (frozen water) should be avoided where possible as melting ice produces large quantities of dirty waste water that may raise concerns of diarrheal disease. Disposal of this waste water creates additional management issues. Temporary burial provides a good option for immediate storage where no other method is available, or where longer term temporary storage is needed. The temperature underground is lower than at the surface, thereby providing natural refrigeration.

Under Chapter 6 of Disaster Victim Identification Guide, bodies should be cooled at $4-6^{\circ} \mathrm{C}$. Only when long-term storage is foreseen, bodies should be kept at sub-zero temperatures $\left(-14^{\circ} \mathrm{C}\right)$ and allowed to warm to $4-6^{\circ} \mathrm{C}$ before examination. A list of bodies placed in each cooling container is to be affixed to the container. A small wall with a height of $0.5 \mathrm{~m}$ can be built around roughly 20 bodies and covered with a tarpaulin or tent. Approximately $10 \mathrm{~kg}$ of dry ice are required for each body per day. No attempt should be made to cool bodies with ice (frozen water), as water may damage both the bodies themselves and especially personal effects (including identification documents).

Methods for identifying human remains has been discussed in Chapter 2 of Guidelines Series. Under the Series, identification of human remains is divided into identification using visual recognition; identification using anthropological studies, cytology, fingerprint comparison, forensic genetics, molecular biology, in particular DNA, and writing analysis, and others. Chapter 6 of the First Responders states that identification is conducted by matching information from 
the deceased (physical features, clothes, etc.) with information from individuals who are missing or presumed dead. Visual recognition of cadavers or their photographs by acquaintances of deceased is the simplest form of identification, but this is prone to errors. Therefore, whenever possible, it should be complemented with other means of forensic identification, albeit at a later stage. Forensic procedures (autopsies, fingerprinting, dental examinations, DNA) can be used after visual identification of bodies or photographs becomes impossible. The early work of nonspecialists in managing the dead (especially proper recovery, documentation and storage methods) will determine much of the success of future identifications by forensic specialists.

Chapter 4 of Disaster Victim Identification Guide described various methods of identification. Victims of a large-scale disaster are identified on the basis of an assessment of multiple factors. The degree to which bodies are damaged, the time bodies have been left exposed and the associated changes in the condition of bodies influence the nature and quality of post mortem data and the applicability of specific methods of identification. Primary methods of identification will involve fingerprint analysis, forensic dental analysis and DNA analysis while secondary methods of identification involve personal descriptions or medical findings and evidence or clothing.

The final disposal of corpses can be conducted by burial or interment has been discussed under Chapter 2 Guidelines Series. It might be necessary to preserve the body until it can be taken to the vigil or public viewing site or finally disposed of. For this reason, preservation is an important issue in the management of massive fatalities in disaster situations. Various methods can be used to preserve the remains of victims, depending on the condition in which corpses are found. It includes the use of low temperatures: the remains are kept in containers that refrigerated with ice or other systems; the use of chemical processes: substances are injected intravenously or placed or injected into the cavities or other parts of the corpse; immersion in liquids; and burial.

Chapter 8 of the First Responders has stated that all identified dead bodies should be released to relatives or their communities for disposal according to local custom and practice. Long-term storage will be required for remaining unidentified bodies. Burial is the most practical method as it preserves evidence for future forensic investigation, if required. Careful thought must be given to the location of any burial site. Soil condition, highest water table level, and available space must be considered. The burial site should be clearly marked and surrounded by a buffer zone that is at least $10 \mathrm{~m}$ wide to allow planting of deep-rooted vegetation and to separate the site from inhabited areas. Under Chapter 12 of Disaster Victim Identification Guide, if no cooling capacities are available or obtainable, temporary graves can be dug to accommodate large numbers of victims as bodies remain cooler when stored underground. Burial trenches can be dug to accommodate large numbers of bodies and body parts. With these trenches should be at least 1.5 metres deep and not located closer than 200 metres from the nearest drinking water source. A gap of $40 \mathrm{~cm}$ should be left between individual corpses. Corpses must not be stacked and the position of each body must be clearly marked.

\section{Suggestion and Conclusion}

Is it suggested that a new treaty regulating the management of human corpse after disaster is needed and the United Nations shall play its role to encourage member States to ratify the proposed treaty. The proposed treaty shall comprise of several important sections namely 
recovery of dead body, storage of dead body, identification of dead body, and disposal of dead body. In addition, the procedure of recovery, storage, identification and disposal of dead body shall be listed down in detail. As such, the existing international law related to management of human corpse which have been identified in this study ( treaties, customary international humanitarian law and soft law) can be incorporated into the new treaty governing the management of human corpse after disaster. With the introduction of the treaty governing the management of human corpse after disaster, it is hoped that the human corpse will be treated with full respect.

\section{Acknowledgment}

The writers would like to express our gratitude to ministry of higher education Malaysia for the funding under research acculturation grant scheme (rags) (ref: rags/1/2015/ss10/unisza/02/1).

\section{References}

Convention (I) for the Amelioration of the Condition of the Wounded and Sick in Armed Forces in the Field https://ihl-

databases.icrc.org/applic/ihl/ihl.nsf/Treaty.xsp?documentld=2F5AA9B07AB61934C1256 3CD002D6B25\&action=openDocument

Convention (II) for the Amelioration of the Condition of Wounded, Sick and Shipwrecked Members of Armed Forces at sea https://ihldatabases.icrc.org/applic/ihl/ihl.nsf/Treaty.xsp?documentld=2F5AA9B07AB61934C1256 3CD002D6B25\&action=openDocument

Convention (III) relative to the Treatment of Prisoner of War https://ihldatabases.icrc.org/applic/ihl/ihl.nsf/Treaty.xsp?documentld=2F5AA9B07AB61934C1256 3CD002D6B25\&action=openDocument

Convention (IV) relative to the Protection of Civilian Persons in Time of War https://ihldatabases.icrc.org/applic/ihl/ihl.nsf/Treaty.xsp?documentld=AE2D398352C5B028C1256 3CD002D6B5C\&action=openDocument

D'Amato, A. (1987) Trashing customary international law. http://anthonydamato.law.northwestern.edu/Adobefiles/a87a-trashing.pdf

Disaster Victim Identification Guide (2014). https://www.interpol.int/INTERPOLexpertise/Forensics/DVI-Pages/DVI-guide

Duhaime, L. (1999) Duhaime's Law Dictionary. Victoria, British Columbia.

Harvey, P., Baghri, S., and Reed, B. (2002). Emergency sanitation, assessment and programme design, Leicestershire, Loughborough University.

Henckaerts, J., and Doswald-Beck, L. (2009) Customary international humanitarian law. Cambridge University Press.

Hildebrandt, A. (2013). Mass burials may complicate Philippines Typhoon Haiyan recovery. http://www.cbc.ca/news/world/mass-burials-may-complicate-philippines-typhoonhaiyan-recovery-1.2430868 http://eprints.maynoothuniversity.ie/392/1/Human_Dignity.pdf 
INTERNATIONAL JOURNAL OF ACADEMIC RESEARCH IN BUSINESS AND SOCIAL SCIENCES

Hutton, D. (2001) Psychosocial aspects of disaster recovery: integrating communities into disaster planning and policy making. https://www.iclr.org/images/Psychosocial_aspects_of_disaster_recovery.pdf

Jha, M. K. (2010) Natural and anthropogenic disasters, vulnerability, preparedness and mitigation. Springer.

Kume, G. D. (2006) Posttraumatic stress: new research. Nova Science Publishers.

Lang, W. (1999) Treaties as a source of international environmental law, Oxford: EOLSS Publication

Law, J., \& Martin, E. A. (2013) Oxford Dictionary. Oxford University Press.

Lebech, M. (2004) What is human dignity? http://eprints.maynoothuniversity.ie/392/1/Human_Dignity.pdf

Morgan, O., Tidball-Binz, M., and Alphen, D.V (2009) Management of Dead Bodies after Disasters: A Field Manual for First Responders, Wahington D.C, Pan American Health Organisation.

Obonyo, R. (2015) We do need a disaster policy. http://www.nation.co.ke/oped/Opinion/Wedo-need-a-disaster-management-policy/-/440808/2715688/-/onstOe/-/index.html

Periago, M. R. (2004) Management of Dead Bodies in Disaster Situations: Disaster Manuals and Guidelines Series, No.5, Wahington D.C, Pan American Health Organisation.

Protocol (I) Additional to the Geneva Convention and relating to the Protection of Victims of International Armed Conflicts https://ihldatabases.icrc.org/applic/ihl/ihl.nsf/Treaty.xsp?documentld=D9E6B6264D7723C3C1256 3CD002D6CE4\&action=openDocument

Protocol (II) Additional to the Geneva Conventions and relating to the Protection of Victims of Non-International Armed Conflicts https://ihldatabases.icrc.org/applic/ihl/ihl.nsf/Treaty.xsp?documentld=AA0C5BCBAB5C4A85C125 63CD002D6D09\&action=openDocument

Rahman, N., and Amin, J. (2014) Role of soft law in international law making process. http://www.sub/edu/bd/.

Statute of the International Court of Justice http://legal.un.org/avl/pdf/ha/sicj/icj_statute_e.pdf

Tidball-Binz, M. (2007) Managing the dead in catastrophes: guiding principles and practical recommendations for first responders, Inter. Review of the Red Cross, 89(866), 421-442. 